\title{
Tetanus-Toxoid Vaccination among Married Women of Reproductive Age (18-49) and its Association with Socio-demographic in Union Council Kamu Shaheed District Ghotki Sindh
}

\author{
Abdul Wahab Somoro, Muhammad Ibrahim Ansari, Ghulam Parwar Soomro, \\ Muhammad Aslam, Muhammad Siddique Ansari, Kaleemullah Abro
}

\begin{abstract}
OBJECTIVE: To determine the factors in influencing for tetanus toxoid vaccination among married women of reproductive age group (18-49) of Ghotki Sindh.

METHODOLOGY: Descriptive cross-sectional study was conducted in UC Kamu-Shaheed, district Ghotki from May 2017 to October 2017. Total sample of reproductive age group women 18-49 years were 323 which was taken though systematic random sampling with confidence interval $0.5 \%$. Results were taken by computing frequencies and association were analyzed through chi-squire.

RESULTS: Two hundred and one (62.2\%) women and seventy one $(22 \%)$ men (husbands of women) were illiterate. Seventy one (22\%) respondents had no knowledge about Tetanus Toxoid vaccine, $292(90.4 \%)$ respondents have received one or more doses of Tetanus toxoid vaccine. $293(90.7 \%)$ respondents expressed that they had LHWs in their areas and $30(9.3 \%)$ denied. $190(58.8 \%)$ respondents expressed fear from injections. $43(13 \%)$ women were completely immunized (received all five doses of Tetanus toxoid), $31(9.6 \%)$ women did not receive any Tetanus toxoid vaccination (zero dose). Variables like distance from home to health facility, education of women, fear of injection, and awareness regarding vaccine were significantly influencing Tetanus toxoid vaccination. Absence of vaccinator, absence of LHWs in the area and absence of female staff at the health facility were among top three influencing factors which scoring of $55 \%, 43.3 \%$, and $39.3 \%$ respectively.

CONCLUSION: Lack of education, transport, access to health care facility, availability of practitioners, knowledge of tetanus and vaccination schedule, availability of vaccines are the factors affecting the introduction of tetanus toxoid in the body of pregnant women.
\end{abstract}

KEYWORDS: Reproductive age, Married women, Tetanus Toxoid, Vaccine, Child bearing age, immunization

This article may be cited as: Somoro AW, Ansari MI, Soomro GP, Aslam M, Ansari MS, Abro K. Tetanus-Toxoid Vaccination among Married Women of Reproductive-age (18-49) and its Association with Socio-demographic in Union Council Kamu Shaheed District Ghotki Sindh. J Liaquat Uni Med Health Sci. 2019;18(04):307-13. doi: 10.22442/jlumhs. 191840648

\section{INTRODUCTION}

Tetanus, commonly called lockjaw is caused by a bacterial toxin or poison that affects the nervous system of the body ${ }^{1}$. Infection spreads contact of any abrasion skin or dead tissue like wound or when the umbilical cord is cut $^{3}$. Tetanus toxoid (TT) vaccine was first produced in $1924^{4}$. Neonatal tetanus in developing countries is $8-50 \%{ }^{5}$. Tetanus Toxoid (TT) vaccination is suggested in the women of reproductive age group all over the world because it develops immunity against the tetanus ${ }^{6}$. To be fully protected against this curse and avoid transmission from mother to her newborn, a woman needs to take 5 doses of tetanus toxoid vaccine during her lifetime and this can be done over period of 3 years ${ }^{1}$. According to the data of WHO about 290,000 citizens worldwide passed away due to tetanus in 2004, in which comprising 257,000 belongs to newborn tetanus ${ }^{7}$. Pakistan is getting efforts to decrease death rates during pregnancy and infancy ${ }^{8}$. TT vaccination for pregnant woman became integrated by WHO Expanded Program on Immunization (EPI) ${ }^{9}$.

In the United States of America, it is also observed that fewer cases are registered at the health facility for treatment ${ }^{10}$. One of the causes had to achieve Millennium Development Goals (MDGs) by the year 2015 and Sustainable Development Goals (SDGs) aims to maintain the same progress by dropping the global maternal deaths ratio to less than 70 per 100,000 live births ${ }^{11}$. Aim of study is to improve TT vaccination coverage among women of reproductive age group (18-49) and objective is to coverage of TT vaccination and to find association with socio 
demographic in Union council Kamu Shaheed District Ghotki Sindh.

\section{METHODOLOGY}

Descriptive Cross-sectional study conducted in Union council Kamu Shaheed of District Ghotki Sindh from May 2017 - October 2017 on married child bearing age women (18-49 years). Systematic random sampling technique was used and sample size calculated on Prevalence Rate of Tetanus Disease $(74 \%) \mathrm{N}=323$. Inclusion criteria were those women who were married in reproductive age (18-49) residing in Union council Kamu Shaheed for last 3 years and at least one pregnancy during her life, mentally unhealthy and widows were excluded. Data was collected by interviewing the married women of reproductive age group women, observing immunization record and in the absence of vaccination card data was taken by recalling and also was confirmed from LHWs' record. Tool were pre-tested on $10 \%$ and translated into local language (Sindhi), it was Pre-structured questionnaire and were used previously ${ }^{12}$. It is of socio-demographic profile and influencing factors for TT vaccination. Data was analyzed on SPSS 20 version. Ethical permission was taken from Institutional Review Board of HSA and written consent was taken from participants and confidentiality was maintained.

\section{RESULTS}

Sample size of three hundred twenty three women who were married and had at least one pregnancy in their life aged from 18 to 49 years. All $(n=323)$ participants were agreed for participation, thus response rate remained $100 \%$.

\section{Socio-demographic}

Frequencies of total respondents (women of reproductive age group 18-49 years), were categorized as; $18-25$ were 104 (32.2\%); 26-33 were $138(42.7 \%)$; $34-41$ were $60(18.6 \%)$ and $42-49$ were $21(6.5 \%)$ Table I.

TABLE I: DEMOGRAPHIC AND POPULATION DYNAMICS STATISTICS

\begin{tabular}{|l|c|r|}
\hline Age of women & Frequency & Percentage \\
\hline $18-25$ & 104 & 32.2 \\
\hline $26-33$ & 138 & 42.7 \\
\hline $34-41$ & 060 & 18.6 \\
\hline $42-49$ & 021 & 6.5 \\
\hline Total & 323 & 100.0 \\
\hline \multicolumn{2}{|l|}{ Occupation of women } \\
\hline House wife & 317 & 98.1 \\
\hline
\end{tabular}

\begin{tabular}{|c|c|c|}
\hline Employee & 06 & 1.9 \\
\hline Total & 323 & 100.0 \\
\hline \multicolumn{3}{|c|}{ Education status of women } \\
\hline Illiterate & 201 & 62.2 \\
\hline Primary & 68 & 21.1 \\
\hline Middle & 11 & 3.4 \\
\hline Metric & 20 & 6.2 \\
\hline Above & 23 & 7.1 \\
\hline Total & 323 & 100.0 \\
\hline \multicolumn{3}{|l|}{ Occupation of husband } \\
\hline Govt. Job & 41 & 12.7 \\
\hline Private job & 37 & 11.5 \\
\hline Skilled & 122 & 37.8 \\
\hline Jobless & 123 & 38.1 \\
\hline Total & 323 & 100.0 \\
\hline \multicolumn{3}{|c|}{ Monthly income of husbands } \\
\hline Less than 5000 PKR & 59 & 18.5 \\
\hline More than $50001 \mathrm{PKR}$ & 108 & 33.4 \\
\hline Less than $10000 \mathrm{PKR}$ & 108 & 33.4 \\
\hline More than $10001 \mathrm{PKR}$ & 48 & 14.9 \\
\hline Total & 323 & 100.0 \\
\hline \multicolumn{3}{|l|}{ Husband education } \\
\hline Illiterate & 71 & 22.0 \\
\hline Primary & 69 & 21.4 \\
\hline Middle & 43 & 13.3 \\
\hline Metric & 72 & 22.3 \\
\hline Above & 68 & 21.1 \\
\hline Total & 323 & 100.0 \\
\hline
\end{tabular}

Out of total 323 participants 317 (98.1\%) were housewives and only 6 women were employee which is $1.9 \%$ of total participants. Monthly income status of women's husband was < 5000 for 59 (18.3\%). Husbands' education status were as 71 (22.0\%) uneducated and $69(21.4 \%)$ were primary pass.

\section{Influencing factors for tetanus toxoid vaccination}

Out of 323 Status of women either who decide at home or not for themselves was as, you (women themselves) were 118(36.5\%), your husband (husbands of women) were $174(53.9 \%)$ and your mother in law (mothers in law of women) were 31 $(9.6 \%)$ Table II. 
Abdul Wahab Somoro, Muhammad Ibrahim Ansari, Ghulam Parwar Soomro, Muhammad Aslam, Muhammad Siddique Ansari, Kaleemullah Abro

TABLE II: INFLUENCING FACTORS FOR TT VACCINATION

\begin{tabular}{|l|r|r|}
\hline Who decides for health at home \\
\hline You & 118 & 36.5 \\
\hline Your husband & 174 & 53.9 \\
\hline Your mother in law & 31 & 9.6 \\
\hline Total & 323 & 100.0 \\
\hline
\end{tabular}

Distance from house to health facility

\begin{tabular}{|l|r|r|}
\hline$<2 \mathrm{~km}$ & 14 & 4.3 \\
\hline$<5 \mathrm{~km}$ & 231 & 71.5 \\
\hline$<10 \mathrm{~km}$ & 66 & 20.4 \\
\hline$>10 \mathrm{~km}$ & 12 & 3.7 \\
\hline Total & 323 & 100.0 \\
\hline
\end{tabular}

Visits to hospital during pregnancy

\begin{tabular}{|l|r|r|}
\hline Yes & 260 & 80.5 \\
\hline No & 63 & 19.5 \\
\hline Total & 323 & 100.0 \\
\hline
\end{tabular}

Presence of female staff while visiting during pregnancy

\begin{tabular}{|l|r|r|}
\hline Yes & 295 & 91.3 \\
\hline No & 28 & 8.7 \\
\hline Total & 323 & 100.0 \\
\hline
\end{tabular}

Do you have any LHWs in your area

\begin{tabular}{|l|r|r|}
\hline Yes & 293 & 90.7 \\
\hline No & 30 & 9.3 \\
\hline Total & 323 & 100.0 \\
\hline
\end{tabular}

Does she visit regularly

\begin{tabular}{|l|r|r|}
\hline Yes & 262 & 81.1 \\
\hline No & 61 & 18.9 \\
\hline Total & 323 & 100.0 \\
\hline
\end{tabular}

Have you heard about neonatal tetanus?

\begin{tabular}{|l|r|r|}
\hline Yes & 228 & 70.6 \\
\hline No & 95 & 29.4 \\
\hline Total & 323 & 100.0 \\
\hline
\end{tabular}

Have you any knowledge about TT vaccine

\begin{tabular}{|l|r|r|}
\hline Yes & 252 & 78.0 \\
\hline No & 71 & 22.0 \\
\hline Total & 323 & 100.0 \\
\hline
\end{tabular}

Out of 323 women, distance of health facility to house was as $<2 \mathrm{~km}$ were $14(4.3 \%),<5 \mathrm{~km}$ were $231(71.5 \%),<10 \mathrm{~km}$ were $66(20.4 \%)$ and $>10 \mathrm{~km}$ were $12(3.7 \%)$. Women out of 227 who got information about vaccination was as, from media were 4(1.7\%) Table III.

TABLE III: INFORMATION ASKED ABOUT TT

\begin{tabular}{|l|r|r|}
\hline Knowledge about schedule of TT vaccine \\
\hline Yes & 227 & 70.3 \\
\hline No & 96 & 29.7 \\
\hline Total & 323 & 100.0 \\
\hline
\end{tabular}

\section{From where you got information}

\begin{tabular}{|l|r|r|}
\hline Media & 31 & 9.6 \\
\hline Friend & 00 & 00 \\
\hline Hospital & 20 & 6.2 \\
\hline LHW & 272 & 84.2 \\
\hline Total & 323 & 100.0 \\
\hline Have you received injections \\
\hline Yes & 292 & 90.4 \\
\hline No & 31 & 9.6 \\
\hline Total & 323 & 100.0 \\
\hline
\end{tabular}

How many injection have you received?

\begin{tabular}{|l|r|r|}
\hline One & 10 & 3.1 \\
\hline Two & 107 & 33.1 \\
\hline Three & 109 & 33.7 \\
\hline Four & 24 & 7.4 \\
\hline Five & 42 & 13.0 \\
\hline None & 31 & 9,6 \\
\hline Total & 323 & 100.0 \\
\hline
\end{tabular}

From where you received these injections

\begin{tabular}{|l|r|r|}
\hline Govt. Hospital & 272 & 84.2 \\
\hline Private hospital & 00 & 00 \\
\hline Vaccinator & 20 & 6.2 \\
\hline Not vaccinated & 31 & 9.6 \\
\hline Total & 323 & 100.0 \\
\hline
\end{tabular}

\begin{tabular}{|l|r|r|}
\hline Presence of vaccinator \\
\hline Yes & 288 & 89.2 \\
\hline No & 31 & 9.6 \\
\hline Don't know & 4 & 1.2 \\
\hline Total & 323 & 100.0 \\
\hline
\end{tabular}


Tetanus-Toxoid Vaccination among Married Women

\begin{tabular}{|c|c|c|}
\hline \multicolumn{3}{|c|}{ Presence of vaccine } \\
\hline Yes & 287 & 88.9 \\
\hline No & 36 & 11.1 \\
\hline Total & 323 & 100.0 \\
\hline \multicolumn{3}{|c|}{ Attitude of vaccinator } \\
\hline Good & 291 & 90.1 \\
\hline Not good & 23 & 7.1 \\
\hline Don't know & 9 & 2.8 \\
\hline Total & 323 & 100.0 \\
\hline \multicolumn{3}{|c|}{ Have you fear about these injections } \\
\hline No & 133 & 41.2 \\
\hline Yes & 190 & 58.8 \\
\hline Total & 323 & 100.0 \\
\hline \multicolumn{3}{|c|}{ No of ANC visits during pregnancy } \\
\hline One & 25 & 7.7 \\
\hline Two & 73 & 22.6 \\
\hline Three & 53 & 16.4 \\
\hline Four & 87 & 26.9 \\
\hline None & 85 & 26.3 \\
\hline Total & 323 & 100.0 \\
\hline \multicolumn{3}{|c|}{ Accessibility of TV or radio } \\
\hline Yes & 220 & 68.1 \\
\hline No & 103 & 31.9 \\
\hline Total & 323 & 100.0 \\
\hline
\end{tabular}

ASSOCIATION IN-BETWEEN VARIABLES

Table IV shows result of association between variables and TT vaccine coverage, most of the variables were significant. For this chi-square was analyzed, p-value and confidence interval was computed. Alpha (0.05) was as the margin of error.

TABLE IV: ASSOCIATION IN-BETWEEN VARIABLES (DEMOGRAPHIC AND FACTORS ITEMS)

\begin{tabular}{|l|c|c|}
\hline \multicolumn{1}{|c|}{ Variables } & P-value & Results \\
\hline $\begin{array}{l}\text { Age women of } \\
\text { reproductive group } \\
18-25 \text { Years } \\
26-33 \text { Years } \\
\text { 34-41 Years } \\
42-49 \text { Years }\end{array}$ & .000 & $\begin{array}{c}\text { Association } \\
\text { found }\end{array}$ \\
\hline $\begin{array}{l}\text { Occupation of women } \\
\text { Housewife } \\
\text { Employee }\end{array}$ & .022 & $\begin{array}{c}\text { No } \\
\text { Association }\end{array}$ \\
\hline
\end{tabular}

\begin{tabular}{|c|c|c|}
\hline $\begin{array}{l}\text { Education of the women } \\
\text { Illiterate } \\
\text { Primary } \\
\text { Middle } \\
\text { Matric } \\
\text { Above } \\
\end{array}$ & .005 & $\begin{array}{l}\text { Association } \\
\text { found }\end{array}$ \\
\hline $\begin{array}{l}\text { Husband occupation } \\
\text { Govt Job } \\
\text { Private Job } \\
\text { Skilled } \\
\text { Jobless }\end{array}$ & .006 & $\begin{array}{l}\text { Association } \\
\text { found }\end{array}$ \\
\hline $\begin{array}{l}\text { Husband education } \\
\text { Illiterate } \\
\text { Primary } \\
\text { Middle } \\
\text { Matric } \\
\text { Above }\end{array}$ & .000 & $\begin{array}{l}\text { Association } \\
\text { found }\end{array}$ \\
\hline $\begin{array}{l}\text { Monthly income } \\
\text { Less than } 5000 \text { PKR } \\
\text { More than } 50001 \text { PKR } \\
\text { Less than } 10000 \text { PKR } \\
\text { More than } 10001 \text { PKR }\end{array}$ & .294 & $\begin{array}{c}\text { No } \\
\text { Association }\end{array}$ \\
\hline
\end{tabular}

Cl 95\%, p-value 0.05

Age of women, education of women, occupation of husband, education of husband, Decision for health at home, How far health facility, Visit at hospital during pregnancy, Presence of lady doctor of LHV at health facility, Regularly visits of LHWs, Knowledge about TT vaccine, Knowledge of vaccination schedule, From where you received vaccination, Presence of vaccinator, Presence of vaccines, Fear of injection, No of ANC visits, and Accessibility of TV or radio had significant result except occupation of women and monthly income.

\section{DISCUSSION}

This study was conducted to determine influencing factors for TT vaccination among the women of reproductive age group. TT vaccination is given against the tetanus, $\mathrm{WHO}$ has recommended $90 \%$ target for vaccination coverage. Women education has significance influence on TT vaccination and a study conducted in Peshawar also supports in which it is shown that those women who were educated and had government job had more awareness and in those women TT coverage was high when we reviewed literature for our study Mother's education also represents strong positive significance with receiving two or more doses of TT injections ${ }^{13}$. Husband occupation also had significance influence on TT vaccination, women whose husbands who were 
skilled or employee had higher percentage of TT vaccination, a study shows that in those women whose husbands had government job or skilled they had higher coverage for TT vaccine Immunization ${ }^{12}$.

Distance of facility far from the house has also high significance influence on TT vaccination as shown in study of Bangladesh in which women were not vaccinated whose house was too far from health facility ${ }^{16}$. In a study conducted in Peshawar, women were not vaccinated due to far distance comparing with those whose home was far from health facility ${ }^{12}$. Presence of lady doctor or LHV or any female staff at the center also significantly influence on TT vaccination as study shows conducted in Peshawar Pakistan, in which it is shown that due to not presence of staff and non-availability of vaccine become the reason for less no of vaccination ${ }^{8}$. Present study shows that respondents, who said unavailability of lady doctor or LHVs, had lesser no of vaccination coverage than those women who said for presence of female staff they had greater no of vaccination coverage. Chi-squire test also shows an association according to its results, in which p-value is less than alpha (0.05) and confidence interval does not lies in between 1 confidence interval which shows a significance result and an association between presence of lady doctor or LHV at the facility and TT vaccine coverage and this study also supports to a previous study ${ }^{13}$. Presence of LHWs and their regular visits in the area also shows significance influence on the coverage of TT vaccination and it is also shown in the study of Peshawar Pakistan which supports this study 6 .

Awareness about tetanus, TT vaccination and schedule of vaccination has shown significance influence on the coverage of TT vaccination, it is also shown in a study from Pakistan conducted at Tertiary care hospital and also shown in USAID's report that lesser no of women had vaccination coverage who were not aware about TT vaccination than those who had greater awareness which support present study $^{14,15}$. Presence of vaccinator and vaccines at health facility has shown significance influence on TT vaccination coverage, a study from Pakistan Tertiary care hospital which shows that not presence of vaccinator and vaccines at health facility is one of the cause of low vaccination coverage which support present study ${ }^{14}$.

Fear of injections showed a significance influence on
TT vaccination, it is also shown in a study from Bangladesh in which it is shown that $(24.6 \%)$ women were those who said that they had fear from injections ${ }^{13} .4 .1 \%$ women were not vaccinated due to fear of injection it is shown in study from Peshawar which also supports present study ${ }^{12}$. Number of ANC visits plays a crucial role in the improvement of TT coverage as shown in study conducted in, which it is shown that more than three ANC visits improve the coverage for TT vaccination. Another study from Indonesia in which it is shown that those women who visited more for ANC, those women were 30 times more likely to vaccinate compared to those who did not have an antenatal care which support present study ${ }^{16}$. Accessibility of TV or radio also has a significance influence on TT coverage a study from Pakistan Peshawar shows the results that women who had access to TV/radio had higher immunization (66.4\%) than those who did not have access to TV/ radio $(23.2 \%)$. Similar findings were found in other studies conducted in Pakistan which shows $10 \%$ of women were not vaccinated due to non availability of TV or Radio, which support this study ${ }^{12}$. The present study also shows that respondents had not availability of radio or TV, they had lesser no of TT coverage than those who had availability of TV or radio as this is one of the source of awareness, chi-square results also show significant because $p$-value is less than 1 and C.I does not lies in between $1 \mathrm{Cl}$, which show an association between accessibility of TV and TT vaccination.

\section{CONCLUSION}

Very low percentage of women were fully immunized (received all five doses of TT), and less than $10 \%$ women did not receive any T.T vaccination(zero dose) most the variables like distance from home to health facility, education of women, fear in injection, awareness, were significantly influencing TT vaccination but absence of vaccinator, absence of LHWs in the area and absence of female staff at the health facility were among top three influencing factors which scored $55 \%, 43.3 \%$, and $39.3 \%$ respectively.

These issues have to be addressed, if any significant progress to maternal neonatal tetanus elimination is to be made. However it is concluded that in spite of these all facts, it is limited study and in a very limited area, for better results it needs broader studies. 


\section{LIMITATION}

Study conducted in small union council which cannot be generalized for the nation and could be recall bias since the women were asked for their vaccination record who had not their vaccination cards.

\section{RECOMMENDATION}

As Pakistan has not achieved target of elimination for tetanus. In our research, we have concluded that there are so many factors which are influencing on TT vaccination coverage these factors are: Occupation of women, education status, distance from health facility, absence of lady doctors or LHVs at health facility, absence of LHWs in the in the area, irregular visiting of LHWs in the area, not knowledge about TT vaccination or tetanus, absence of vaccinator and vaccines at the health facility. Looking at these influencing factors, we recommend to improve literacy rate in particular of women, make sure for the presence of lady doctors or LHVs, Vaccinators and availability of vaccine at the health facilities. Training to LHWs for the counseling in the community about awareness and the importance of TT vaccines and tetanus, deployment of LHWS in the vacant areas, proper supply and store of vaccination under recommended temperature and also monitoring and supervision over the vaccination activities in those areas where vaccination coverage is low and surveillance is also recommended for tetanus, so that actions may be taken against in the time.

Ethical permission: Ministry of National Health Regulation and Coordination Services, Government of Pakistan approval letter dated: 23-05-2017.

Conflict of interest: Authors of the study have no conflict of interest to declare.

Funding: None.

\section{REFERENCES}

1. Khan R, Vandelaer J, Yakubu A, Raza AA, Zulu F. Maternal and neonatal tetanus elimination: from protecting women and newborns to protecting all. Int J Women's Health. 2015; 7: 171-80. doi: 10.2147/IJWH.S50539.

2. Fields KL, Brockes JP, Mirsky R, Wendon LM. Cell surface markers for distinguishing different types of rat dorsal root ganglion cells in culture. Cell. 1978; 14(1): 43-51.

3. World Health Organization. Maternal immuniza- tion against tetanus. [Internet]. WHO. Available from: https://www.who.int/reproductivehealth/ publications/maternal_perinatal_health/ immunization_tetanus.pdf

4. Anokye M, Mensah JA, Frimpong FO, Aboagye EO, Acheampong N. Immunization Coverage of Pregnant Women with Tetanus Toxoid Vaccine in Dormaa East District-Brong Adaro Region, Ghana. MTM. 2014; 4(6): 47-57.

5. Verma R, Khanna P. Tetanus toxoid vaccine: Elimination of neonatal tetanus in selected states of India. Human Vaccines \& Immunotherapeutics. 2012; 8(10): 1439-42. doi:10.4161/hv.21145.

6. Afridi NK, Hatcher J, Mahmud S, Nanan D. Coverage and factors associated tetanus toxoid vaccination status among females of reproductive age in Peshawar. J Coll Physicians Surg Pak. 2005; 15(7): 391-5.

7. Esen B, Kurtoglu D, Coplu N, Gozalan A, Miyamura K, Ishida $\mathrm{S}$, et al. Tetanus Immunization Status among Women of Childbearing Age in Turkey. Jpn $\mathrm{J}$ Infect Dis. 2007; 60(2-3): 92-6.

8. Gul R, Bibi S, Khan HM, Ayub R, Alam SR, Afridi A. Frequency of Tetanus Toxoid vaccination in pregnant women attending a tertiary care hospital. J Med Sci(Peshawar). 2016; 24(4): 220-3.

9. Singh A, Pallikadavath S, Ogollah R, Stones W. Maternal Tetanus Toxoid Vaccination and Neonatal Mortality in Rural North India. PLoS One. 2012; 7(11): e48891. doi. 10.1371/ journal. pone.0048891.

10. Thwaites CL, Loan HT. Eradication of tetanus. $\mathrm{Br}$ Med Bull. 2015; 116: 69-77.

11. Wilson RJ, Paterson $P$, Jarrett $C$, Larson HJ. Understanding factors influencing vaccination acceptance during pregnancy globally: A literature review. Vaccine. 2015; 33(47): 6420-9. doi: 10.1016/j.vaccine.2015.08.046.

12. Naeem M, Khan MZ, Abbas SH, Adil M, Khan A, Naz SM, et al. Coverage and factors associated with tetanus toxoid vaccination among married women of reproductive age: a cross sectional study in Peshawar. 2010; 22(3): 136-40.

13. Rahman M. Determinants of the utilization of the tetanus toxoid (TT) vaccination coverage in Bangladesh: Evidence from a Bangladesh Demographic Health Survey 2004. Internet J Health. 2008; 8(2): 1-7. 
14. Nisar N, Aziz N, Mumtaz F. Tetanus Toxoid vaccination coverage among pregnant women at Tertiary Care Hospital, Sindh Pakistan. Medical Channel. 2010; 16(2): 272-5.

15. Research and Development Solutions. Policy briefs. [Internet]. June 11, 2012. Available from: https://www.resdev.org/policy_briefs.
16. Roosihermiatie B, Nishiyama M, Nakae K. Factors associated with TT (tetanus toxoid) immuzization among pregnant women, in Saparua, Maluku, Indonesia. Southeast Asian J Trop Med Public Health. 2000; 31(1): 91-5.

AUTHOR AFFILIATION:

Abdul Wahab Somoro

Divisional Monitoring Officer

Health Department

Provincial Dengue Program

Sukkur, Sindh-Pakistan.

\section{Muhammad Ibrahim Ansari}

(Corresponding Author)

Lecturer

SMBB Medical University

Larkana, Sindh-Pakistan.

Email: cadetccl@yahoo.com

Dr. Ghulam Parwar Soomro

District EPI Officer

Qambar Shahdad Kot, Sindh-Pakistan.

\section{Dr. Muhammad Aslam}

Medical Officer

PPHI, Shaheed Benazirabad, Sindh-Pakistan.

\section{Muhammad Siddique Ansari}

Department of Pharmacy

Liaquat University of Medical \& Health Sciences

Jamshoro, Sindh-Pakistan.

Dr. Kaleemullah Abro

Medical Officer

CMC Hospital, Larkana, Sindh-Pakistan. 